Хміль-Чуприна Віта Вімаліївна, викладач кафедри філології та видавничої справи Кременчуцького національного університету імені Михайла Остроградського inmov.krnu@gmail.com https://orcid.org/0000-0002-2466-5352

\title{
ФОРМУВАННЯ ЧИТАЦЬКОЇ КОМПЕТЕНЦЇ̈ І КУЛЬТУРИ У СТУДЕНТСЬКОЇ МОЛОДІ В ПРОЕКТІ «КНИГА У ВІРТУАЛЬНОМУ ПРОСТОРІ»
}

Мета дослідження - визначити сучасний інструментарій формування читацької компетениії $i$ культури у студентської молоді, зокрема методи і засоби популяризачії читання, та проаналізувати ефективність їх упровадження. У статті розглядаються можливі сучасні иляхи формування у студентської молоді інтересу до читання. Методологія дослідження передбачає застосування загальнонаукових та спеціальних методів опису, порівняльного аналізу та узагальнення результатів емпіричного дослідження, методу проектів для перевірки ефективності формування читачькоі компетенції $і$ культури. Наукова новизна дослідження полягає в тому, щцо за допомогою реалізації спрямованих на популяризачію читання проектів з'ясовано, що формування читащької компетениіі i культури у студентської молоді найшвидше відбувається завдяки залученню до проектів усіх зачікавлених сторін - освітніх та соціокультурних установ, бібліотек, засобів масової комунікації $i$ студентської молоді. Висновки. Визначено, що на сьогодні інтернет-ЗМК і сочіальні мережі надважливі для популяризаиії читання, зокрема, серед студентської молоді. Тому у студентських проектах, спрямованих на промоцію та пропагування книг, запропоновано такі жанри: інтернетанотації, відеорецензії, букстаграми, теледайджести. Представлено в динаміці зростання запитів і продажів рекламованих книжкових видань. Зроблено висновок про ефективність вибраних жанрів реклами та пропагування книг і рекламно-промоційних заходів.

Ключові слова: популяризація читання, формування інтересу до читання у студентської молоді, пропагування читання, відеорецензія на книгу, теледайджест книжкових видань, букстаграм.

Хмиль-Чуприна Вита Витальевна, преподаватель кафедры филологии и издательского дела Кременчугского национального университета имени Михаила Остроградского

\section{ФОРМИРОВАНИЕ ЧИТАТЕЛЬСКОЙ КОМПЕТЕНЦИИ И КУЛЬТУРЫ У СТУДЕНЧЕСКОЙ МОЛОДЕЖИ В ПРОЕКТЕ «КНИГА В ВИРТУАЛЬНОМ ПРОСТРАНСТВЕ»}

Цель исследования - определить современный инструментарий формирования читательской компетенции и культуры у студенческой молодежи, в частности методы и средства популяризации чтения, и проанализировать эффективность их внедрения. В статье рассматриваются возможные современные пути формирования у студенческой молодежи интереса $к$ чтению. Методология исследования заключается в применении общенаучных и спещиальных методов описания, сравнительного анализа и обобщения результатов эмпирического исследования, метода проектов для проверки эффективности формирования читательской компетенции и культуры. Научная новизна исследования заключается в том, что с помощью реализащии направленных на популяризацию чтения проектов выяснено, что формирование читательской компетенции и культуры у студенческой молодежи быстрее происходит благодаря привлечению к проектам всех заинтересованных сторон - образовательных и сочиокультурных учреждений, библиотек, средств массовой коммуникации и студенческой молодежи. Выводы. Определено, что сегодня интернет-СМК и социальные сети играют важную роль в популяризации чтения, в частности, среди студенческой молодежи. Поэтому в студенческих проектах, направленных на продвижение и пропаганду книг, предложены следующие 
жанры: интернет-аннотации, видеорецензии, букстаграмы, теледайджесты. Представлен в динамике рост запросов и продаж рекламируемых книжных изданий. Сделан вывод об эффективности выбранных жанров рекламы и пропаганды книг и рекламно-промоционных мероприятий.

Ключевые слова: популяризачия чтения, формирования интереса к чтению у студенческой молодежи, пропаганда чтения, видеорецензия на книгу, теледайджест книжных изданий, букстаграм.

Khmil-Chupryna Vita,

lecturer of philology and publishing department, Kremenchuk Mykhailo Ostrohradskyi National University

\section{FORMATION OF STUDENT YOUTH'S READING COMPETENCE AND CULTURE DUE TO THE START-UP "BOOK IN VIRTUAL ENVIRONMENT"}

The purpose of the article is to identify modern tools for the formation of student youth's reading competence and culture, in particular methods and means of popularization of reading, to analyze the effectiveness of their implementation. In the article, possible modern ways of the formation of student youth's reading interest are considered. The methodology of research is to apply general scientific and specific methods of description, comparative analysis, and generalization of the empirical research results, method of projects to check the effectiveness of reading competence and culture formation. The scientific novelty of the research is that through the implementation of readership-oriented start-ups, it has been found out that forming of student youth' reading competence and culture is most likely due to the involvement in start-ups of all stakeholders: educational and socio-cultural institutions, libraries, mass media, and student youth. The potential of mass media in the popularization of reading and establishing effective communication between all stakeholders involved in this process has been proved. Conclusions. It has been determined that online mass media and social networks are essential for the popularization of reading, particularly among student youth. Therefore, for the student start-ups that aimed at promotion and popularization books, genres like online annotations, video reviews, bookstagrams, television digests are offered. Through the implementation of the start-up "Book in a virtual environment,» the effectiveness of the popularization of reading literature using mass media proved. Growth of the advertised book editions requests and sales is represented in dynamics. A conclusion about the effectiveness of selected genres of books' advertising and promotion and promotional activities made.

Key words: popularization of reading, forming of student youth' reading interest, reading promotion, video book review, TV book digest, bookstagram.

Актуальність теми дослідження зумовлена необхідністю пошуку нових шляхів і форм поширення в суспільстві позитивного ставлення до читання, залучення до цього різновиду діяльності молоді, яка зараз орієнтується переважно на отримання інформації у віртуальному середовищі і віддає преференцію не текстовому, а візуальному формату.

Традиційно аналіз проблеми формування читацької компетенції і культури здійснювався в межах досліджень у галузі маркетингу або бібліотечної справи, що, попри усю безперечну цінність таких спостережень, не давало можливості повного його осягнення, вивчення тенденцій, охоплення усіх можливих шляхів просування книжок та формування інтересу до читання у студентської молоді.

Аналіз останніх досліджень і публікацій. Вивченню теоретичних і практичних питань реклами та промоції книжкових видань, книжкового маркетингу присвячені роботи О. Антоник та О. Жолдак [1], Т. Сжижанська [4], формування інтересу до читання у сучасних умовах грунтовно досліджують А. Бессараб [3], I. Копистинська та Т. Гринівський [8], А. Судин [11], К. Цуїмото (К. Tsujimoto) [12], проблеми формування читацької культури серед студентської молоді визначають Л. Бакуменко [2], О. Квасова та Н. Лямзіна [7], Г.-А. Мельничук [9], роль інтернету і ЗМК у популяризації книжок простежують Н. Зелінська [5], К. Калугіна [6], О. Скочинець [10]. 
Проте досі бракує концептуальних інтегративних досліджень цієї проблеми у соціально комунікаційній парадигмі, що належним чином відображували б роль ЗМК у популяризації читання, зокрема, серед студентської молоді, тому всебічний аналіз шляхів, практичних засобів і способів пропагування книжок і читання у ЗМК $є$ актуальним.

Мета дослідження - визначити сучасний інструментарій формування читацької компетенції і культури у студентської молоді, зокрема методи і засоби популяризації читання, та проаналізувати ефективність їх упровадження. Завдання дослідження полягають у тому, щоб висвітлити способи привернення уваги студентської молоді до літератури у ЗМК, довести роль ЗМК у популяризації читання шляхом проведення емпіричного дослідження, розробити та упровадити проект «Книга у віртуальному просторі», спрямований на популяризацію книги і розвиток читацької культури студентської молоді.

Методологія дослідження передбачає застосування загальнонаукових та спеціальних методів систематизації наукових публікацій, опису етапів дослідження, порівняльного ана- лізу та узагальнення результатів емпіричного дослідження, методу проектів.

Виклад основного матеріалу дослідження. Для виконання поставлених завдань дослідження були визначені такі методи і засоби: застосування методу проектів, активне залучення засобів масової комунікації (ЗМК), інтернет-ЗМК, зокрема соціальних мереж Facebook та Instagram. Викладачами кафедри філології та видавничої справи Кременчуцького національного університету імені Михайла Остроградського (КрНУ) було запроваджено проект «Книга у віртуальному просторі». Стейкхолдери проекту (зацікавлені у результаті сторони) - установи і організації Кременчука: Кременчуцький національний університет імені Михайла Остроградського (КрНУ), Кременчуцька міська централізована бібліотечна система для дорослих, книжковий магазин «Роксолана», Кременчуцька міська телерадіокомпанія (ТРК); інформаційний портал «Кременчук Тудей».

Реалізація проекту «Книга у віртуальному просторі» складалася 3 трьох етапів: формувального, організаційно-проектного i контрольного (табл. 1).

\section{Етапи реалізації проекту «Книга у віртуальному просторі»}

\begin{tabular}{|c|c|c|c|}
\hline $\begin{array}{l}\text { № } \\
\text { 3/II }\end{array}$ & Назва етапу & Результати & Стейкхолдери \\
\hline 1. & Формувальний & $\begin{array}{l}\text { створення } \\
\text { контенту }\end{array}$ & $\begin{array}{l}\text { КрНУ, Кременчуцька міська централізована } \\
\text { бібліотечна система для дорослих }\end{array}$ \\
\hline 2. & $\begin{array}{l}\text { Організаційно- } \\
\text { проектний }\end{array}$ & $\begin{array}{l}\text { створення рубрик } \\
\text { i програм у ЗМК }\end{array}$ & $\begin{array}{l}\text { КрНУ, книжковий магазин «Роксолана», Кременчуцька } \\
\text { міська ТРК, інформаційний портал «Кременчук Тудей» }\end{array}$ \\
\hline 3. & Контрольний & $\begin{array}{l}\text { оцінка } \\
\text { ефективності } \\
\text { проекту }\end{array}$ & $\begin{array}{l}\text { КрНУ, Кременчуцька міська централізована } \\
\text { бібліотечна система для дорослих, книжковий магазин } \\
\text { «Роксолана» }\end{array}$ \\
\hline
\end{tabular}

Формувальний етап передбачав формування у студентів компетентності фахового оцінювання i характеристики літературних творів і книжкових видань, створення студентами контенту, спрямованого на рекламу книг і популяризацію читання. Організаційнопроектний етап мав на меті організацію у міських засобах масової комунікації спеціалізованих рубрик і програм, спрямованих на рекламу книг і популяризацію читання. На контрольному етапі перевірялися результати проекту: рівень читацької культури студентів, кількість запитів і обсяги продажів книг.

Для формувального етапу були обрані такі жанри реклами книг, як анотації, відеорецензії і букстаграми. Вибір саме цих жанрів був зумовлений їх належністю до різних жарових блоків: інформаційного 
(анотації), аналітичного (відеорецензії) та художнього (букстаграм). Це мало на меті сформувати у студентів навички різноманітної характеристики і оцінки літературних творів i книжкових видань. Спочатку студентам університету було запропоновано складання анотацій нових книжкових надходжень до Кременчуцької міської централізованої бібліотечної системи для дорослих. Анотації розміщувалися на сайті бібліотеки (рис. 1).

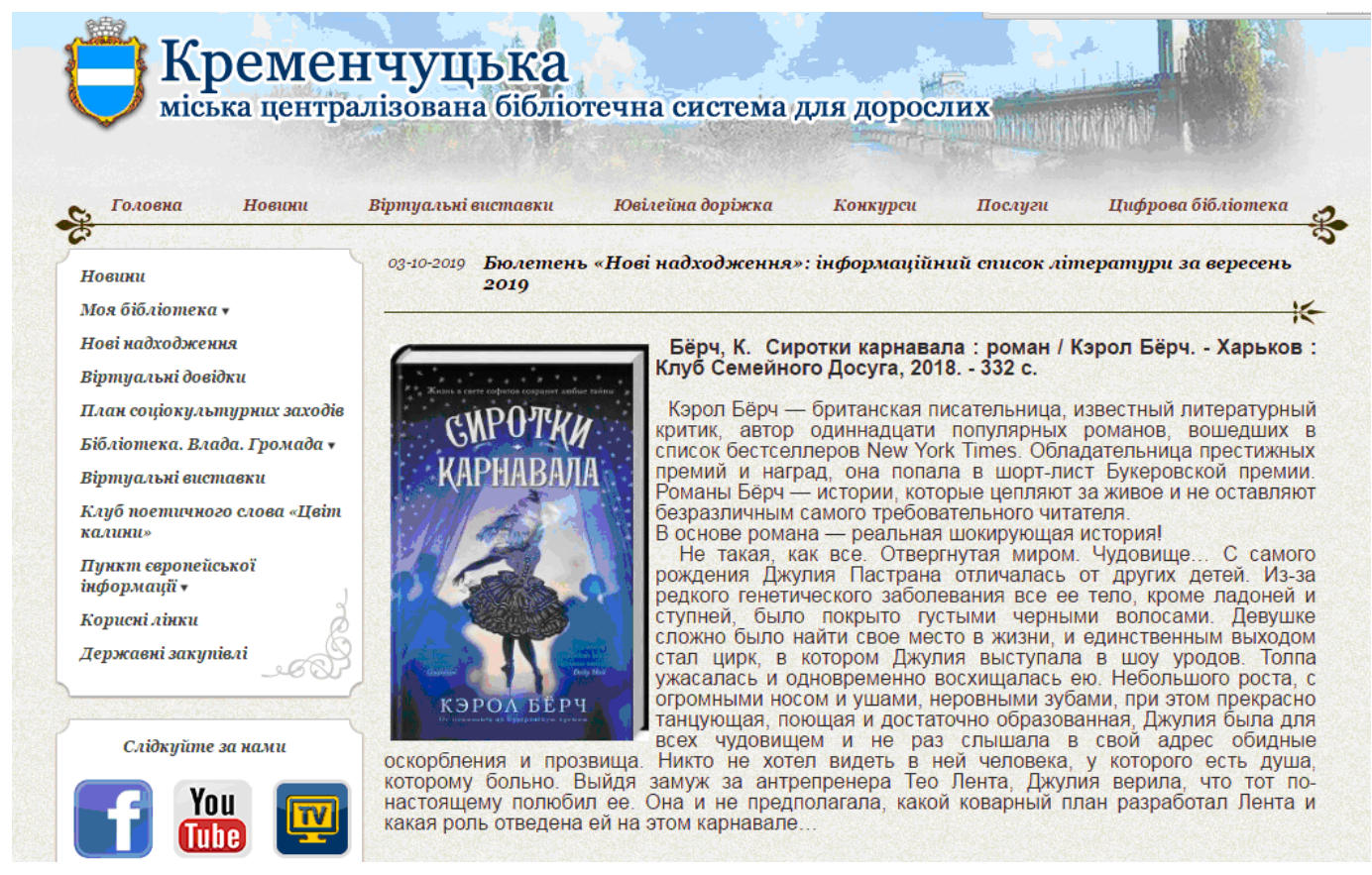

Рисунок 1. Зразок анотації на сайті бібліотеки

Метою написання анотацій є промоція видань серед студентської молоді і пропагування читання. Вибір жанру анотації зумовлений тим, що він є більш легким для створення журналістами-початківцями порівняно 3 рецензією чи буктрейлером, оскільки анотація передбачає мінімум аналітичних та художньопубліцистичних елементів. Написання анотацій це, передусім, творчий процес, який передбачає фахове опрацювання книжкової продукції, адже майстерно і професійно написана анотація $є$ запорукою привернення уваги широкого кола читачів, спонукає придбати видання та формує інтерес до читання.

У межах реалізації проекту «Книга у віртуальному просторі» студентами було створено 68 анотацій книжкових видань. Написання анотацій книжкових видань студентами сприяло досягненню двох цілей: привернення уваги широкого загалу до літературних новинок і формування у студентів навичок фахової характеристики книжкової продукції.
Наступним кроком стало створення відеорецензій (відеороликів, у яких автор показує книгу і характеризує іiі) книжкових надходжень до Кременчуцької міської централізованої бібліотечної системи для дорослих. Вибір аудіовізуальної форми рецензії був зумовлений тим, що проект спрямований, передусім, на студентську молодь, для якої така форма подачі матеріалу більш звична і прийнятна.

У межах реалізації проекту студентами було знято відеорецензії до 51 книжкового видання. Відеорецензії викладено на сторінці Facebook Кременчуцької міської централізованої бібліотечної системи для дорослих (ЦБС).

За свідченням працівників Кременчуцької ЦБС після оприлюднення відеорецензій збільшився відсоток запитів рекламованих книжкових видань у бібліотеці (зафіксовано зростання на 7-12\%).

Наступним кроком у реалізації проекту «Книга у віртуальному просторі» стало ство- 
рення студентами букстаграмів «Моя улюблена книга» на сторінках у соціальній мережі Instagram і на сайті Кременчуцької ЦБС.

За період реалізації проекту студентами було створено 42 фотографії в букстаграмах, розміщених в Instagram. Зразки букстаграмів подано на рис. 2.

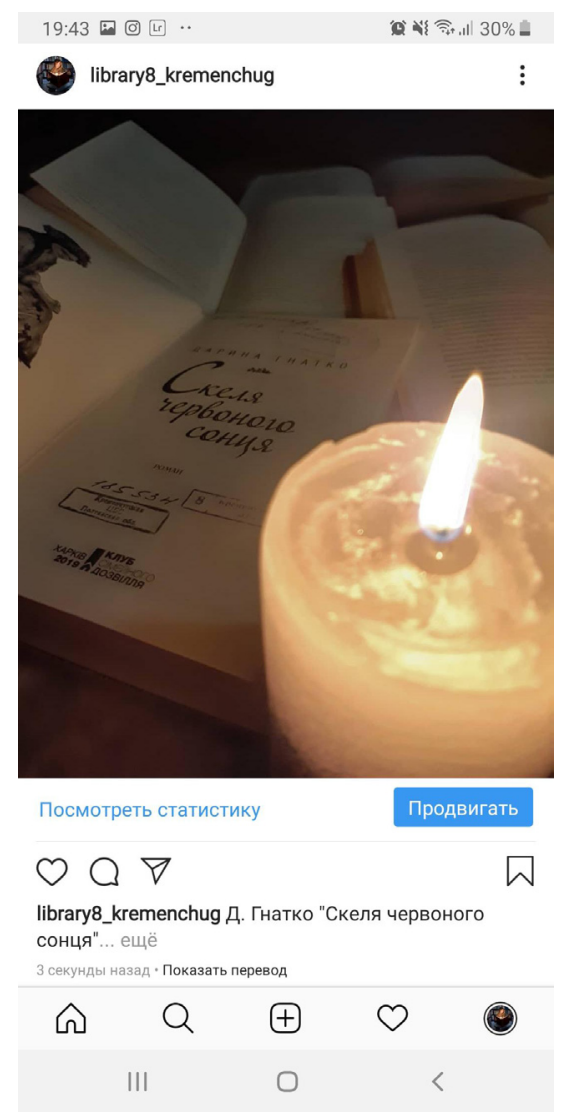

a)

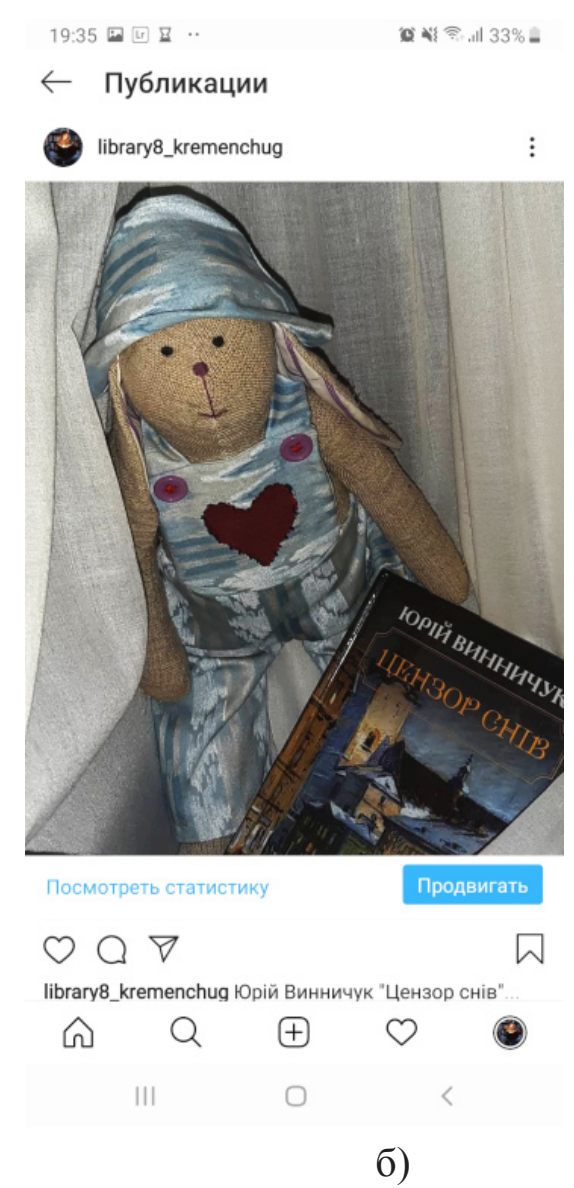

б)

Рисунок 2. Зразки студентських букстаграмів, розміщених у мережі Instagram

Букстаграм виявився ефективним інструментом для просування книг і встановлення зворотного зв'язку з потенційними читачами. Результатом впровадження цієї практики стало зростання кількості запитів у бібліотеці (на $6 \%$ і продажів рекламованих видань у книжковому магазині «Роксолана» (на 3,5 \%).

Також у межах реалізації проекту студенти долучилися до створення, розробки дизайну та підтримки сторінок бібліотек у соціальних мережах. Так, студентка спеціальності «Журналістика» Анастасія Шаповалова є редактором соціальної сторінки «library8_kremenchug» філії № 8 Кременчуцької міської централізованої бібліотечної системи для дорослих. На цій сторінці вона розміщує анотації та фото нових надходжень до бібліотеки (див. рис. 2, а).
На організаиійно-проектному етапі у засобах масової комунікації Кременчука було створено спеціалізовані рубрики і програми, спрямовані на рекламу книжок і популяризацію читання.

Зокрема, Кременчуцькоюміськоютелерадіокомпанією у межах ранкової інформаційнорозважальної програми «Xistory» було запроваджено раз на два тижні теледайджест книжкових видань (тривалість чотири хвилини, ведуча - студентка спеціальності «Журналістика» Анна Литвин).

Головною метою створення україномовної інформаційно-освітньої програми «Xistory» було бажання зробити для глядачів телеканалу цікавою і доступною історію видатних подій та відомих людей. Тому, пере- 
дивляючись безліч історичних програм та читаючи велику кількість книжок, у команди Кременчуцької міської телерадіокомпанії виникла ідея розповідати про історію легкою і доступною мовою.

Перший випуск було створено 12 червня 2018 року. Глядачі каналу зацікавилися новою програмою, у соціальних мережах з'явилися позитивні відгуки та прохання продовжити випуск інформативної і цікавої програми.

Наразі історичне україномовне шоу «Xistory» містить декілька окремих рубрик, зокрема: відеорозповідь про видатних історичних постатей України та світу; відеорозповідь про історичні події; відеонарис «Цей день в історії світу».

Той самий дайджест, але у текстовому форматі заплановано викладати на міському інформаційному порталі «Кременчук Тудей», де для цих цілей створюється спеціальна рубрика. Готуються книжкові дайджести студентами Кременчуцького національного університету імені Михайла Остроградського, редагуються працівниками відповідних ЗМК.

Наукова новизна дослідження полягає в тому, що за допомогою реалізації спрямованих на популяризацію читання проектів з'ясовано, що формування читацької компетенції і культури у студентської молоді найшвидше відбувається завдяки залученню до проектів усіх зацікавлених сторін - освітніх та соціокультурних установ, бібліотек, засобів масової комунікації і студентської молоді.
Висновки. Отже, за результатами аналізу відеорецензій і теледайджестів книжкових видань можна дійти висновку, що сучасну студентську молодь переважно цікавлять сучасні жанри р канали просування інформації про книги i. Варто зауважити, що анотації, написані студентами, як показала практика, викликають більш високу довіру у молодіжної аудиторії, ніж ті, що створюються працівниками бібліотечних установ. При цьому преференція надається різноманітній фантастиці (науковій фантастиці, фентезі, містиці, трилеру тощо) $\mathrm{i}$ соціально-психологічному роману.

Формат інформаційно-розважальної програми, спрямованої на огляд книжкових видань (теледайджест), у тематичному аспекті виявився дуже сприятливим для теледайджесту книжкових новинок, адже цільова аудиторія програми і телевізійної реклами книг перетинається. Глядачі, які цікавляться історією, водночас $\epsilon$ потенційними читачами книжок.

Загалом результати упровадження проекту «Книга у віртуальному просторі» доводять, що на сьогодні інтернет-ЗМК і соціальні мережі відіграють важливу роль у популяризації читання, зокрема, серед студентської молоді. Подальші дослідження передбачають реалізацію контрольного етапу для перевірки ефективності проекту «Книга у віртуальному просторі» за певними критеріями. На цьому етапі перспективним було б визначення кола читацьких уподобань студентської молоді.

\section{Список використаних джерел}

1. Антоник О. В., Жолдак О. О. Книжкові конкурси як засіб активізації попиту на книжкову продукцію. Поліграфія і видавнича справа. 2014. № 3 (67). С. 73-81.

2. Бакуменко Л. Г. Молодь і книга: реалії та майбутнє. Бібліотеки ВНЗ України у процесі імплементації Закону «Про вищу освіту» та інформатизації суспільства: матеріали Всеукраїнської науково-практичної конференції (Івано-Франківськ, 16-19 червня 2015 р.). Івано-Франківськ: НТБ ІФНТУНГ, 2015. С. 10-14.

3. Бессараб А. Соціально-комунікаційний аспект формування інтересу до книги за допомогою Інтернету. Інформація, комунікація, суспільство 2016: матеріали 5-ої Міжнародної наукової конференції ІКС-2016, (Львів, Славське, 19-21 травня 2016 р.) / Національний університет «Львівська політехніка». Львів: Вид-во Львівської політехніки, 2016. С. 132-133.

4. Сжижанська Т. Використання українськими книговидавництвами інтернет-платформ для комунікації із цільовими аудиторіями. Сучасний мас-медійний простір: реалії та перспективи розвитку: матеріали II Всеукраїнської наук.-практ. конф. (Вінниця, 12-13 жовтня 2016 р.) / наук. ред. В. М. Каленич. Вінниця, 2016. С. 301-307.

5. Зелінська Н. М. Просування книжкових видань у традиційних та новітніх українських медіа 
у контексті європейської практики. Наукові записки Інституту журналістики. 2014. Т. 56. С. 96-99.

6. Калугіна К. В. Деякі аспекти популяризації книги через інтернет. Інформащійне суспільство. 2015. Вип. 21. С. 54-58.

7. Квасова О. Г., Лямзіна Н. К. Формування інтегрованих умінь читання й письма у процесі виконання студентами веб-квесту. Ars Linguodidacticae. 2018. Вип. 2. С. 38-44.

8. Копистинська I., Гринівський Т. Засоби промоції книжкових видань: досвід незалежної України. Наукові записки [Української академії друкарства]. Серія: Соціальні комунікації. 2015. № 1. C. 37-46. URL: http://nbuv.gov.ua/UJRN/Nzck_2015_1_7.

9. Мельничук, Г.-А. Б. Нові форми та методи розвитку інтересу до читання у студентів медичного університету. Бібліотеки ВНЗ України у процесі імплементації Закону «Про вищу освіту» та інформатизаиії суспільства: матеріали Всеукр. наук. конф. (Івано-Франківськ, 16-19 черв. 2015 р.) / ред. Пилип Я. А., Цок Л. В., Тачинська О. Б., Степашкіна Т. В. Івано-Франківськ: НТБ ІФНТУНГ, 2015. C. 193-202.

10. Скочинець О. Роль електронних медіа у здійсненні акцій книжкової промоції. Теле- $m a$ радіожурналістика. 2010. № 9. Ч. 1. С. 253-257.

11. Судин А. Ю. Формування читача як суб’єкта книжкового ринку: інтеграція зусиль. Поліграфія і видавнича справа. 2011. № 1. С. 44-51.

12. Tsujimoto K. Motivation and Reading Achievement: Understanding the Needs and Motivation Processes of Adult Literacy Learners. Ontario: Brock University St. Catharines, 2015. 104 p. URL: https:// pdfs.semanticscholar.org/d483/bd8540826217568fb9cb491fc24502cedbcf.pdf.

\section{References}

1. Antonik, O. V, Zholdak, O. O. (2014). Book competitions as a means of increasing demand for books. Printing and publishing, 3(67), 73-81. [in Ukrainian].

2. Bakumenko, L. G. (2015). Youth and the book: realities and the future. Libraries of Ukrainian universities in the process of implementation of the Law «On Higher Education» and informatization of society. Proceedings of the Ukrainian Scientific and Practical Conference. (p. 10-14). Ivano-Frankivsk: NTB IFNTUNG. [in Ukrainian].

3. Bessarab, A. (2016). The social and communication aspect of interest in the book through the Internet. Proceedings of the $5^{\text {th }}$ International Scientific Conference "Information, Communication, Society 2016" (IKS 2016). (p. 132-133). Lviv: Edition of Lviv Polytechnic. [in Ukrainian].

4. Yezhizhanska, T. (2016). Using Ukrainian Book Publishers Online Platforms to Communicate with Target Audiences. Proceedings of the $2^{\text {nd }}$ Ukrainian Science-Practice. Conf. "Contemporary Media Space: Realities and Prospects for Development”. (p. 301-307). Vinnitsa. [in Ukrainian].

5. Zelinska, N. M. (2014). The promotion of book publications in traditional and modern Ukrainian media in the context of European practice. Scientific notes of the Institute of Journalism, 56, 96-99. [in Ukrainian].

6. Kalugina, K. V. (2015). Some aspects of book promotion via the Internet. Information Society, 21, 54-58. [in Ukrainian].

7. Kvasova, O. G., Lyamzina, N. K. (2018). Formation of integrated reading and writing skills in the course of students' fulfillment of a web quest. Ars Linguodidacticae, 2, 38-44. [in Ukrainian].

8. Kopystynska, I., Grinivsky, T. (2015). Means of promotion of books: experience of independent Ukraine. Scientific Notes [Ukrainian Academy of Printing]. Series: Social Communications, 1, 37-46. Retrieved from http://nbuv.gov.ua/UJRN/Nzck_2015_1_7. [in Ukrainian].

9. Melnychuk, G.-A. B. (2015). New forms and methods of developing interest in reading at medical university students. Proceedings of the Ukrainian Sciences Conf. "Libraries of Ukrainian universities in the process of implementation of the Law "On Higher Education» and informatization of the society". (p. 193202). Ivano-Frankivsk: NTB IFNTUNG. [in Ukrainian].

10. Skochinets, O. (2010). The role of electronic media in the promotion of book promotion. Television and radio journalism, 9(1), 253-257. [in Ukrainian].

11. Sudin, A. Yu. (2011). Formation of the reader as a subject of the book market: integration of efforts. Printing and publishing, 1, 44-51. [in Ukrainian].

12. Tsujimoto, K. (2015). Motivation and Reading Achievement: Understanding the Needs and Motivation Processes of Adult Literacy Learners. Ontario: Brock Univ. St. Catharines. Retrieved from https:// pdfs.semanticscholar.org/d483/bd8540826217568fb9cb491fc24502cedbcf.pdf. [in English]. 